Received 23.01.2018 Reviewed 20.02.2018 Accepted 09.03.2018

A - study design

B - data collection

C - statistical analysis

D - data interpretation

$\mathbf{E}$ - manuscript preparation

F - literature search

\section{Assessment of metallic contamination in sediment and mullet fish (Mugil cephalus Linnaeus, 1758) tissues from the East Algerian coast}

\author{
Naouel OUALI ${ }^{1), 2) ~ A B D E F}$, Bourhane E. BELABED ${ }^{\text {1) AF }}$ \\ Fadila ZEGHDOUDI $^{2)}$ EF , Mounira RACHEDI ${ }^{2)}$ CDE $\bowtie$
}

\footnotetext{
1) Annaba University, Department of Marine Sciences, Badji Mokhtar, BP 12, Annaba, 23000, Algeria; e-mail: sihemoualinaouel@gmail.com

2) University of El-Tarf, Department of Marine Sciences, Chadli Bendjedid, BP 73, El-Tarf, 36000, Algeria; e-mail: liliazerdoudi24@gmail.com, rachedi.mounira@yahoo.fr
}

For citation: Ouali N., Belabed B.E., Zeghdoudi F., Rachedi M. 2018. Assessment of metallic contamination in sediment and mullet fish (Mugil cephalus Linnaeus, 1758) tissues from the East Algerian coast. Journal of Water and Land Development. No. 38 p. 115-126. DOI: 10.2478/jwld-2018-0048.

\begin{abstract}
The present work was designed to assess the contamination level in the coastal of Annaba, following the spectrophotometric determination of the level of some metallic elements ( $\mathrm{Fe}, \mathrm{Cu}, \mathrm{Pb}, \mathrm{Zn}, \mathrm{Ni}$ and $\mathrm{Cd}$ ) in the sediments along an increasing bathymetric gradient $(10 \mathrm{~m}$ and $20 \mathrm{~m})$, as well as in the biological indicator grey mullet (Mugil cephalus) muscle. During the winter period (2014), 12 surface sediment samples, and a total of 24 fish were collected. Once the samples are dried, crushed and sieved, $0.5 \mathrm{~g}$ dry weight of each sample was added to concentrated acids. The results showed that the levels of some metals are superior to the recommended guideline values, and consequently the sediment of this bay is contaminated by iron, lead and copper. The contamination index $(C I)$ showed a general tendency in the concentration of the studied metals as follows: $\mathrm{Fe}>\mathrm{Pb}>\mathrm{Cu}>\mathrm{Zn}>$ $\mathrm{Ni}>\mathrm{Cd}$, since the most studied metals occurred at higher concentration in depth $(20 \mathrm{~m})$.

However, the average concentrations of metals in fishes were found to be as the following order: $\mathrm{Fe}>\mathrm{Zn}>$ $\mathrm{Pb}>\mathrm{Cu}>\mathrm{Ni}>\mathrm{Cd}$. The consumption of fish from some contaminated sites can be dangerous because concentrations of lead, cadmium and zinc exceed the international standards. Moreover, the strong positive correlation observed between the metallic elements of sediments and fishes confirm that these metals resulted from the similar sources of the anthropic activities, such as domestic, port, industrial and agricultural waste discharges. This is confirmed by the determined of pollution load index $(P L I)$ parameter. Conclusively, a regular monitoring program of heavy metal is recommended for protecting these organisms, and to reduce the environmental risks.
\end{abstract}

Key words: fish, heavy metals, sediment, toxicity, water depth

\section{INTRODUCTION}

The metallic contamination of the aquatic environment has become a world concern, due to their toxicity, bioaccumulation and the harmful effects on aquatic living organisms (fauna, flora and microorganisms), in which the metallic residues accumulate in their soft tissues. Human are exposed to these toxic metals through consumption of contaminated water and food also can be targeted the metallic residues affect the aquatic life [YAKINOV et al. 2007]. The pollution by trace metals, that considered to be as the normal components of the environment at trace levels [BRYAN 1984], but they may become toxic above 
a certain threshold concentration [KUCUKSEZGIN et al. 2006].

Heavy metals are pollutants whose harmfulness is related to their persistence and toxicity, some of them are known as essential elements (zinc, iron and copper) that play a crucial role in the biological processes, and others considered as non-essential elements (no role in the biological processes) able to induce toxic effects when their concentration exceeds certain threshold of acceptability [CHEN et al. 2016; LAFABRIE et al. 2007]. Because they neither be metabolized not be excreted by the biological processes, and therefore they accumulate in various components of the ecosystem (water, sediment, flora, and fauna). Due to the cumulative effects of trace metallic elements in plants and trophic chain, serious environmental and even human health problems are strongly associated to metal contamination [LENOBLE et al. 2013]. Moreover, toxic metals cause harmful effects on physiological functions, individual growth rates, reproduction and mortality of aquatic living organisms [RUQIA et al. 2015; YUJUN et al. 2011]. The uptake of heavy metals in fish follows three possible pathways: the body surface, the gill or the digestive tract, following three exposure sources: food, water and sediment. Importantly, the sediment is a milieu in which the micropollutants may be accumulated and fixed for a long-term period, and thus their analysis is valuable tool for the determination of pollution level [BUGGY, TOBIN 2008]. Noteworthy, the coastal areas known as urbanized and industrialized areas are strongly exposed to high waste discharges of heavy metals due to anthropic activities [PEKEY 2006]. In these regards, the study was focused on the Annaba Gulf (NorthEast of Algeria) known as one of the principal gulfs in
Algeria. The gulf is exclusively fed from the water of Seybouse River, which is considered the vital source for the north-eastern regions of Algeria, however, it undergoes serious environmental pollution problems due to permanent urban and industrial discharges [BELABED et al. 2017]. The aim of our study, therefore, was to evaluate the chemical pollution level in Annaba Gulf, in order to understand its health state, and subsequent to find out the best management ways and protection of its coastal zones. Here, we carried out the estimation of the contamination by the six heavy metals, respectively, $\mathrm{Zn}, \mathrm{Cu}, \mathrm{Pb}, \mathrm{Fe}, \mathrm{Ni}$ and $\mathrm{Cd}$ in the sediments using the contamination index and the biological indicator mullet (Mugil cephalus), known as bio accumulative species for metals, as well as widely used species as a best indicator for metal pollution.

\section{MATERIALS AND METHODS}

\section{DESCRIPTION OF THE STUDY ZONE}

The study zone is located in the extreme East part of the Algerian coast, $600 \mathrm{~km}$ from Algiers and 100 $\mathrm{km}$ from the Tunisian border. The Annaba Gulf of is a wide-mouthed bay, open to the Mediterranean Sea on the North, extending from Cap-Rose $\left(8^{\circ} 1^{\prime} \mathrm{W}\right.$ and $\left.36^{\circ} 58^{\prime} \mathrm{N}\right)$ in the East to Cap de Garde $\left(7^{\circ} 47^{\prime} \mathrm{E}\right.$ and $\left.36^{\circ} 58^{\prime} \mathrm{N}\right)$ in the West, with a distance of $40 \mathrm{~km}$ between them. The Seybouse River in the South-East, the second longest river in Algeria (with a catchment basin of about $6470 \mathrm{~km}^{2}$ ) located in the South-East part, and the Mafrag River in the East drain into the gulf [BELABED et al. 2013]. The two rivers receive agricultural water discharges from cereal farming,

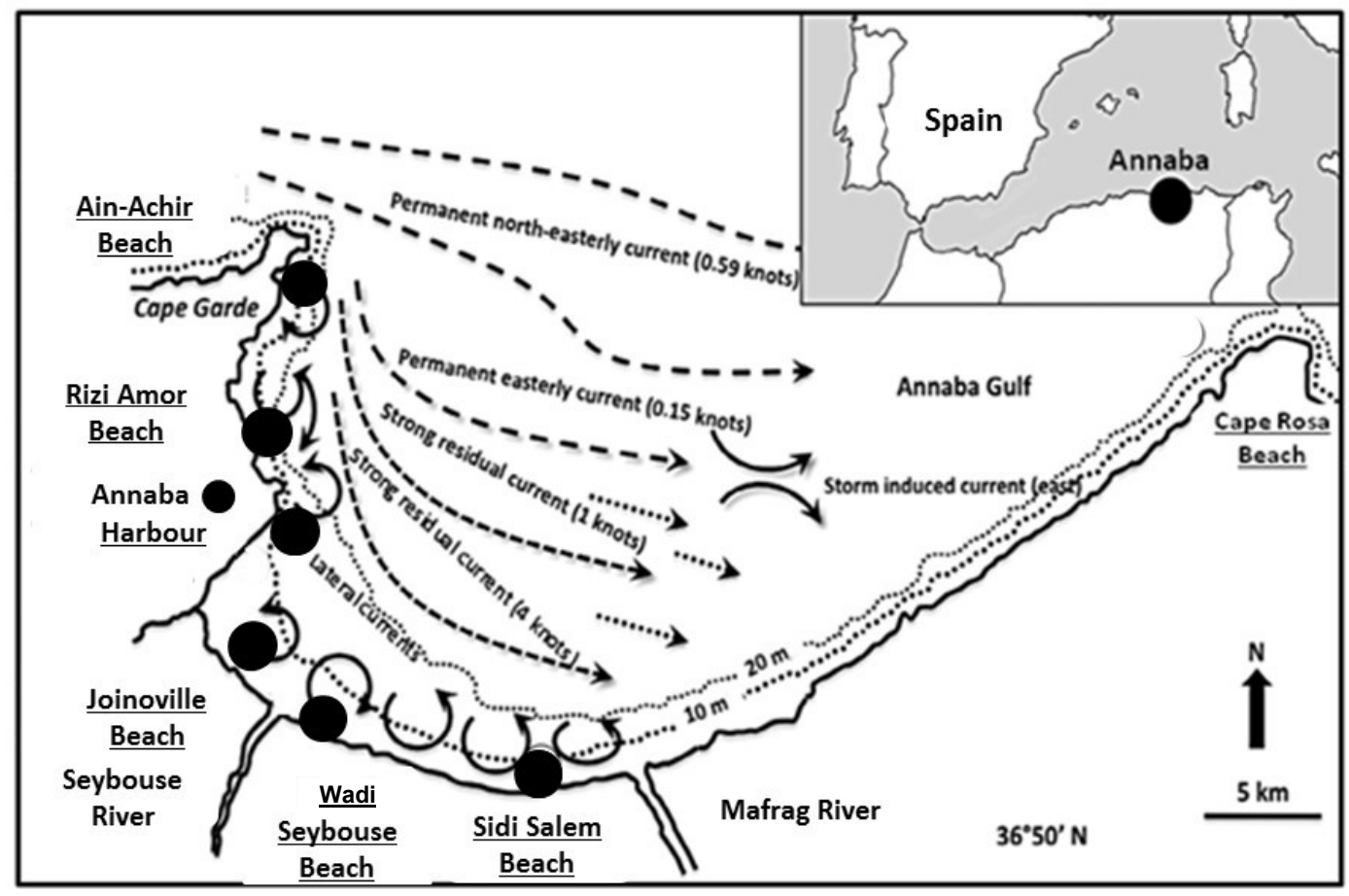

Fig. 1. Location of the sampling sites along of Annaba Gulf; source: BELABED et al. [2013], modified 
market gardening and arboriculture, and domestic releases from important conurbations [KHELIFI-TOUHAMI et al. 2006] and untreated sewage [ABDENNOUR et al. 2000] contributing to sediment contamination by heavy metals. Moreover, discharges from industries, which settle in the lower part of the Meboudja River, the final tributary of the Seybouse River, are important source points of heavy metals measured in the Annaba Gulf superficial sediments. The gulf has a Mediterranean climate characterized by an annual mean temperature of $18^{\circ} \mathrm{C}$ and precipitations ranging from 650 to $1000 \mathrm{~mm}$, mainly distributed in winter (60-70\% of total precipitation) and, therefore, winters are cold and humid, since summers are worm and dry. Additionally, the gulf is subjected to a dominant seabreeze with a speed reaching $6 \mathrm{~m} \cdot \mathrm{s}^{-1}$ from the NorthNorth-East (30\%), and, to a lesser extent, from the north $(13 \%)$ and the west $(10 \%)$ [DEBIECHE 2002]. The maximal depth of the gulf is $65 \mathrm{~m}$.

The sampling points were chosen in relation to locations of human activities that may be the source of pollution, namely the proximity of constructions, pipe spillway of wastewater, as well as the industrial zone (Fig. 1, Tab. 1).

Table 1. Main industries discharging wastes into Annaba Gulf [ABHA 1999].

\begin{tabular}{|c|c|c|c|}
\hline Station & Coordination & Source of pollution & Type of pollution \\
\hline $\begin{array}{l}\text { Sidi } \\
\text { Salem }\end{array}$ & $\begin{array}{l}36^{\circ} 51^{\prime} 42^{\prime \prime} \mathrm{N} \\
07^{\circ} 46^{\prime} 59^{\prime \prime} \mathrm{E}\end{array}$ & urban wastes & $\begin{array}{l}\text { domestic waste } \\
\text { water }\end{array}$ \\
\hline $\begin{array}{l}\text { Wadi } \\
\text { Sey- } \\
\text { bouse }\end{array}$ & $\begin{array}{l}36^{\circ} 52^{\prime} 03^{\prime \prime} \mathrm{N} \\
07^{\circ} 46^{\prime} 29^{\prime \prime} \mathrm{E}\end{array}$ & $\begin{array}{l}\text { urban and industrial } \\
\text { wastes: (ORELAIT, } \\
\text { E.N.C.C, Ferrovial, } \\
\text { Tils-Granito) }\end{array}$ & $\begin{array}{l}\text { domestic waste } \\
\text { water } \\
\text { waters of cooling } \\
\text { industrial waste } \\
\text { waters }\end{array}$ \\
\hline $\begin{array}{l}\text { Joino- } \\
\text { ville }\end{array}$ & $\begin{array}{l}36^{\circ} 52^{\prime} 14^{\prime \prime} \mathrm{N} \\
07^{\circ} 46^{\prime} 10^{\prime \prime} \mathrm{E}\end{array}$ & $\begin{array}{l}\text { urban and industrial } \\
\text { wastes (Asmidal) }\end{array}$ & $\begin{array}{l}\text { domestic waste } \\
\text { waters } \\
\text { industrial waste } \\
\text { waters } \\
\text { waters of cooling }\end{array}$ \\
\hline $\begin{array}{l}\text { Har- } \\
\text { bour }\end{array}$ & $\begin{array}{l}36^{\circ} 53^{\prime} 40^{\prime \prime} \mathrm{N} \\
07^{\circ} 46^{\prime} 30^{\prime \prime} \mathrm{E}\end{array}$ & $\begin{array}{l}\text { urban and industrial } \\
\text { wastes: (Véadu, } \\
\text { E.N.C.G, O.N. food } \\
\text { of livestock n }{ }^{\circ} 1 \text { ) }\end{array}$ & $\begin{array}{l}\text { domestic waste } \\
\text { waters } \\
\text { industrial waste } \\
\text { waters }\end{array}$ \\
\hline $\begin{array}{l}\text { Rizi } \\
\text { Amor }\end{array}$ & $\begin{array}{l}36^{\circ} 55^{\prime} 39^{\prime \prime} \mathrm{N} \\
07^{\circ} 45^{\prime} 16^{\prime \prime} \mathrm{E}\end{array}$ & urban wastes & $\begin{array}{l}\text { domestic waste } \\
\text { waters }\end{array}$ \\
\hline $\begin{array}{l}\text { Ain- } \\
\text { Achir }\end{array}$ & $\begin{array}{l}36^{\circ} 57^{\prime} 599^{\prime \prime} \mathrm{N} \\
07^{\circ} 47^{\prime} 42^{\prime \prime} \mathrm{E}\end{array}$ & there are no wastes & - \\
\hline
\end{tabular}

Source: own elaboration.

\section{COLLECTION AND PREPARATION OF SAMPLES}

The Figure 1 shows the location of six sampling stations: Sidi Salem Beach (St1) (36 $51^{\circ}$ '42" N and $07^{\circ} 46$ '59” E), located in the eastern part of the study area, close to the outlet of the Mafrag River; Wadi Seybouse Beach (St2) (36 52'03' N and 07'46'29' E), known as Wadi Seybouse in referring to Seybouse River that flows into it, receives agricultural, industrial and urban waste from the west valley of the city of Annaba; Joinoville Beach (the industrial zone of Asmidal) (St3) (36 $52^{\prime} 14^{\prime \prime} \mathrm{N}$ and $\left.07^{\circ} 46^{\prime} 10^{\prime \prime} \mathrm{E}\right)$, located in the North-East of the city of Annaba in the munici- pality of El Bouni, near Annaba harbour; harbour station (St4) $\left(36^{\circ} 53^{\prime} 40^{\prime \prime} \mathrm{N}\right.$ and $07^{\circ} 46^{\prime} 30^{\prime}$ ' E), is located in the centre of the city of Annaba, ensures the transit of passengers and merchandise, it is subject to various sources of pollution; Rizi Amor Beach (St5) (36 $55^{\circ} 39^{\prime \prime} \mathrm{N}$ and $07^{\circ} 45^{\prime} 16^{\prime \prime} \mathrm{E}$ ), is part of the west coast of Annaba Gulf, receives also urban waste; AinAchir Beach (St6), is part of the extreme west of the coastal zone, this point is located between $36^{\circ} 57^{\prime} 59^{\prime \prime}$ $\mathrm{N}$ and $07^{\circ} 47^{\prime} 42^{\prime \prime} \mathrm{E}$ and supposed to be exposed to no sources of pollution (Tab. 1).

The twelve (12) samples of surface sediments were collected from a river depth of $10 \mathrm{~m}$ and $20 \mathrm{~m}$, within winter period (25.12.2014). Samples of $250 \mathrm{~g}$ of surface sediments were scraped from a polyethylene shovel. The samples were taken in polyethylene containers, transported in icebox to laboratory, and afterwards they were stored at $4^{\circ} \mathrm{C}$ until being analysed [PNUE 1985]. The Mugil cephalus fish sampling is also carried out during a winter season at the same period for the same stations situated in the west section of the Gulf. A total of 24 fishes, grouped as 4 fishes per site, along with average total length $(T L)$ of $25.7 \pm$ $2.69 \mathrm{~cm}(22.7 \leq T L \leq 31.3 \mathrm{~cm})$ and average total weight $(T W)$ of $87.05 \pm 5.62 \mathrm{~g}(77.45 \leq T W \leq 95.55 \mathrm{~g})$ were studied.

\section{ANALYTICAL PROCEDURE AND ANALYSIS}

All the laboratory plastics and glassware were cleaned by soaking overnight in nitric acid solution of $10 \%$, followed by rinsing with bidistilled water. The dried sediments placed in stove at $80^{\circ} \mathrm{C}$ during 48 hours were crushed in agate mortar, then sieved into fine powder, and only the particles smaller than 65 $\mu \mathrm{m}$ in diameter were collected for later use. Indeed, the fine particles are generally rich in pollutants, and contain a large part of clay levels. A quantity of $0.5 \mathrm{~g}$ of dry weight sediments was mixed with $0,01 \mathrm{dm}^{3}$ of $\mathrm{HNO}_{3}$ (ultra-pure) and $0.05 \mathrm{dm}^{3}$ of $\mathrm{HCLO}_{4}$ (ultrapure) at a temperature of $150^{\circ} \mathrm{C}$ during 16 hours, in order to obtain a good digestion. The mineralized residues were subjected to a consecutive rinsing in bidistilled water, filtered with Whatman filter $(0.45$ $\mathrm{mm}$ ), and afterwards the solution was completed to a final volume of $0.1 \mathrm{dm}^{3}$ with distilled water [SALMONS, FÖRSTNER 1984].

The concentration $\left(C\right.$, in $\left.\mathrm{mg} \cdot \mathrm{kg}^{-1}\right)$ of metallic element in the sediment is obtained according JOANNY et al. [1983] as follow:

$$
C=C E \cdot V / M
$$

Where: $V=$ the final volume of solution after digestion $\left(\mathrm{cm}^{3}\right) ; M=$ mass of the mineralized sediment (kg); $C E=$ the concentration read from the calibration curve $\left(\mathrm{mg} \cdot\left(0.001 \mathrm{dm}^{3}\right)^{-1}\right)$.

Each sample of fish (muscle) was carefully dissected. To prevent the metal contamination, special care has been taken into account, and the tissues were dissected with special ceramic knife, scissors and 
plastic clips. After that fish muscle samples from each individual were cleaned with bidistilled water, cut out into small pieces $(2-3 \mathrm{~cm})$ and dried overnight in oven at $65^{\circ} \mathrm{C}$ [UNEP 1982]. Then were pulverized and sieved through $1 \mathrm{~mm}$ of size mesh, the dried fish muscles were digested as described elsewhere [RAHMAN et al. 2012]. Approximately $0.5 \mathrm{~g}$ of tissues as a dried powder was added to concentrated nitric acid $\left(0.004 \mathrm{dm}^{3}\right)$ and concentrated sulfuric acid $(0.0025$ $\mathrm{dm}^{3}$ ) [UNEP 1982; 1984]. Then the mixture was heated slowly during $20 \mathrm{~min}$ at $130^{\circ} \mathrm{C}$. As a result, the mixture was filtered by Whatman filter $(0.45 \mathrm{~mm})$, and thereafter the solution was completed to a final volume of $0.01 \mathrm{dm}^{3}$ with distilled water. The detection of heavy metals $(\mathrm{Zn}, \mathrm{Cu}, \mathrm{Pb}, \mathrm{Fe}, \mathrm{Cd}$ and $\mathrm{Ni}$ ) in the all samples (sediments and fish) was carried out according flame atomic absorption spectrometric method as described by AMINOT and CHAUSSEPIED [1983].

All elements were afterwards expressed as $\mathrm{mg} \cdot \mathrm{kg}^{-1}$ of dry weight. The detection limits of heavy metals in sediment and fish samples for cadmium $(\mathrm{Cd})$, copper $(\mathrm{Cu})$, iron $(\mathrm{Fe})$, nickel $(\mathrm{Ni})$, lead $(\mathrm{Pb})$ and zinc $(\mathrm{Zn})$ were $0.02,0.03,0.04,0.06,0.06$ and $0.05 \mathrm{mg} \cdot \mathrm{kg}^{-1}$, respectively. The precision of the method was checked by several measurements on the standard reference materials of the International Agency for Atomic Energy (IAAE): IAEA-407 (fish tissue) and IAEA-SL-1 (riparian sediment). Recoveries were above $90 \%$ for all the heavy metals measured. Results are indicated in Table 2.

Table 2. Certified and observed values of trace metal concentrations in reference materials (biota - IAEA-407, sediment - IAEA-SL-1), in $\mathrm{mg} \cdot \mathrm{kg}^{-1}$ dry weight \pm standard deviation

\begin{tabular}{|c|c|c|c|c|}
\hline \multirow{2}{*}{$\sum^{\frac{\pi}{0}}$} & \multicolumn{2}{|c|}{ Biota } & \multicolumn{2}{|c|}{ Sediments } \\
\hline & $\begin{array}{l}\text { certified acc. } \\
\text { to IAEA-407 }\end{array}$ & observed & $\begin{array}{l}\text { certified acc. } \\
\text { to IAEA-SL-1 }\end{array}$ & observed \\
\hline $\mathrm{Zn}$ & $67.1 \pm 3.8$ & $65.5 \pm 0.7$ & $223 \pm 10$ & $228.04 \pm 14.08$ \\
\hline $\mathrm{Cu}$ & $3.28 \pm 0.40$ & $3.52 \pm 0.18$ & $30.0 \pm 5.6$ & $34.03 \pm 6.39$ \\
\hline $\mathrm{Pb}$ & $0.12 \pm 0.06$ & $0.137 \pm 0.006$ & $37.7 \pm 7.4$ & $37.29 \pm 8.95$ \\
\hline $\mathrm{Cd}$ & $0.189 \pm 0.019$ & $0.187 \pm 0.003$ & $0.260 \pm 0.050$ & $0.26 \pm 0.06$ \\
\hline $\mathrm{Fe}$ & n.r. & n.r. & $6.74 \pm 0.17$ & $6.54 \pm 0.27$ \\
\hline $\mathrm{Ni}$ & n.r. & n.r. & $44.9 \pm 8.0$ & $49.13 \pm 7.47$ \\
\hline
\end{tabular}

Explanation: n.r. $=$ non-certified values for the concentrations of some elements in IAEA-407.

Source: own elaboration.

\section{QUALITY STANDARDS}

From a regulatory viewpoint, the metallic pollution treatment in the surface sediments and the fish tissues differs from one country to another. In Table 3, we noticed the allowable limits linked to the superficial marine sediments known by the French laws [ABRMC 1991], as well as at the fish tissue levels compared to allowable maximal limits recommended by the world health organization [WHO 2004] and the Environmental Protection Agency of USA [USEPA 2002].
Table 3. International security standards of heavy metals in sediments and fish

\begin{tabular}{|c|c|c|c|}
\hline \multirow{2}{*}{$\begin{array}{c}\text { Heavy } \\
\text { metal }\end{array}$} & \multirow{2}{*}{$\begin{array}{c}\text { Sediments acc. to } \\
\text { ABRMC [1991] }\end{array}$} & $\begin{array}{c}|c| \\
\text { WHO [2004]/ } \\
\text { USEPA [2002] }\end{array}$ & CE [2006] \\
\cline { 2 - 4 } & & \multicolumn{3}{|c|}{$\mathrm{mg} \cdot \mathrm{kg}^{-1} \mathrm{dwt}$} \\
\hline $\mathrm{Ar}$ & 10 & - & - \\
\hline $\mathrm{Cd}$ & 0.6 & 1 & 0.05 \\
\hline $\mathrm{Cu}$ & 26 & 30 & - \\
\hline $\mathrm{Cr}$ & 45 & 1 & - \\
\hline $\mathrm{Pb}$ & 22 & 2 & - \\
\hline $\mathrm{Zn}$ & 88 & 100 & - \\
\hline $\mathrm{Fe}$ & 2000 & - & - \\
\hline $\mathrm{Mn}$ & 400 & 1 & - \\
\hline $\mathrm{Ni}$ & 45 & $0.5-1$ & - \\
\hline
\end{tabular}

Source: own elaboration acc. to literature.

In the case of French standards, the evaluation of the contamination index values ( $C I$, or guideline) used in the present study for the surface sediments are comparable to those of the Agency of Rhone-Mediterranean and Corsica Basin [ABRMC 1991]. Interestingly, the contamination index $(C I)$ represents the ratio between the reference value of given heavy metal and its level in the studied sediment.

If $C I$ is inferior to 3 , the sediment is considered as class 1 (normal zone), the sediment is of class 2 (polluted zone) when $C I$ is between 3 and 10 , since the sediment belongs to class 3 (risk zone) when $C I$ is superior than 10 .

The evaluation of contamination degree was also done by using the pollution load index (PLI). The later has been widely used to evaluate the contamination level and the pollution in the estuarine and coastal sediments.

The following equation to calculate $P L I$ has been developed by TOMLINSON et al. [1980]:

$$
\begin{gathered}
P L I=\left(F C_{1} \cdot F C_{2} \cdot F C_{3} \cdot \ldots \cdot F C_{n}\right)^{1 / n} \\
F C=C_{\text {metal }} / C_{\text {background }}
\end{gathered}
$$

Where: $F C=$ the contamination factor, $n=$ the number of the analysed elements, $C_{\text {metal }}=$ the concentration of element in the sediment, $C_{\text {background }}=$ the geochemical background value of the element.

The mean comparisons of the spatial data of heavy metal concentrations in the superficial sediments and fish muscle were tested by ANOVA. The relation between the analysed elements $(\mathrm{Zn}, \mathrm{Cu}, \mathrm{Pb}$, $\mathrm{Fe}, \mathrm{Ni}$ and $\mathrm{Cd}$ ) in the sediment and M. cephalus of Annaba Gulf was tested by using the Pearson correlation coefficient, with a significance levels: $p \leq 0.05$, $p \leq 0.01$ and $p \leq 0.001$.

\section{RESULTS AND DISCUSSION}

\section{METALLIC LEVELS IN THE SEDIMENT}

The results relative to the trace element concentrations in superficial sediments of the study zone are given in Figure 2. The calculated contamination index 

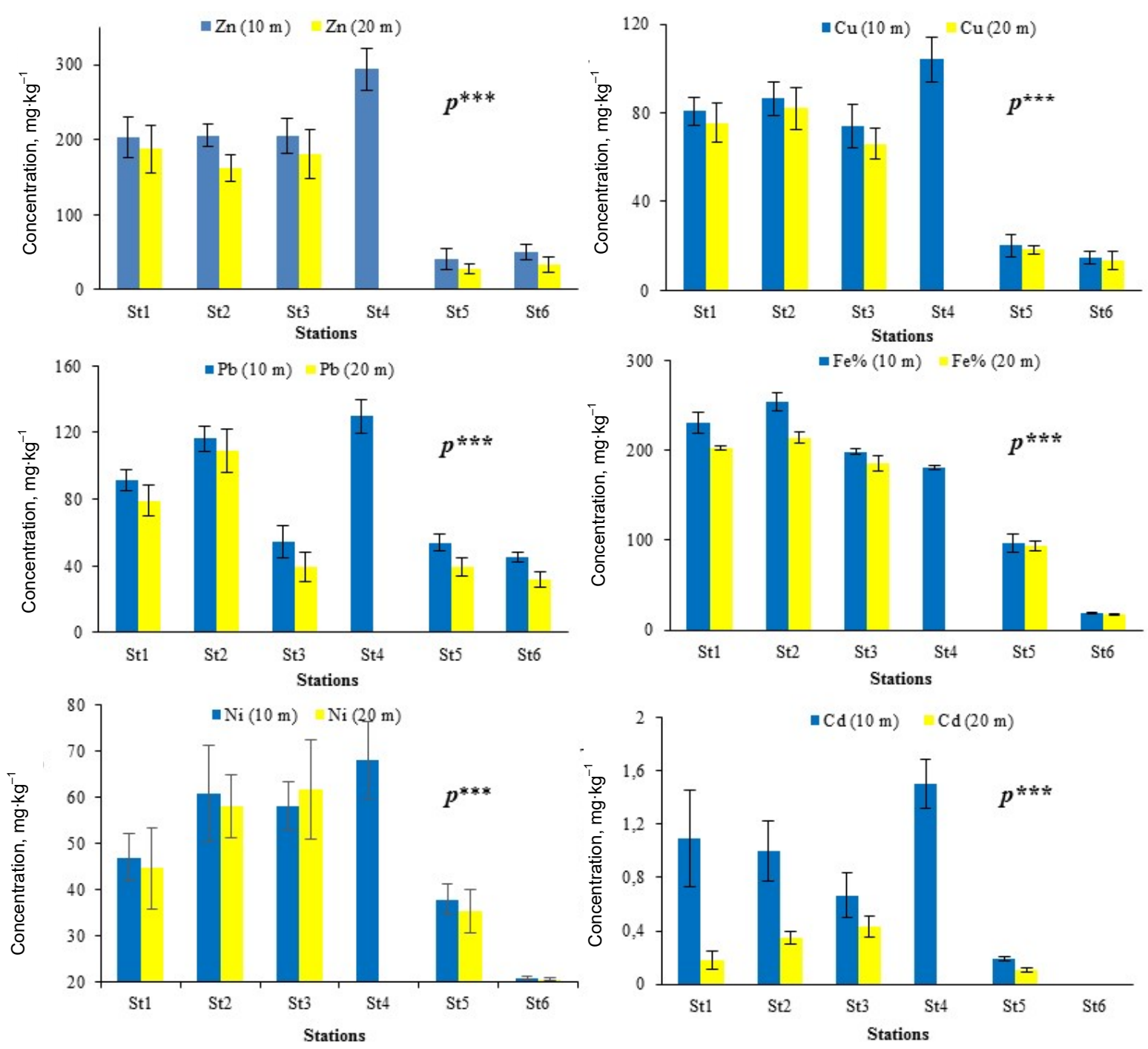

Fig. 2. Average concentrations of metals in sediments ( $\mathrm{mg} \cdot \mathrm{kg}^{-1}$ dry weight) of the six selected stations: Sidi Salem Beach (St1); Wadi Seybouse Beach (St2); Joinoville Beach (the industrial zone of Asmidal) (St3; harbour station (St4); Rizi Amor Beach (St5); Ain-Achir Beach (St6); $p \leq 0.001$; source: own study

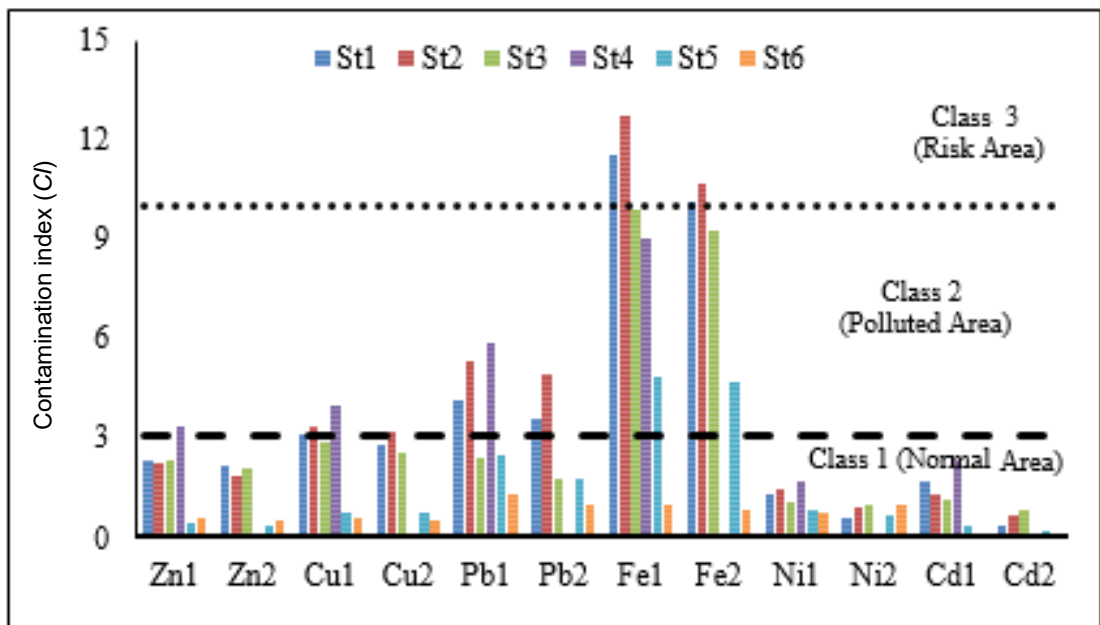

Fig. 3. Variations of the contamination index $(C I)$ of various metals in the Annaba Gulf $(1=10 \mathrm{~m} ; 2=20 \mathrm{~m})$; St1-St6 as in Fig. 2; own study 
(CI) for every analysed metal in the sediments of six stations varies generally from one station to another (Fig. 3). Since the iron is an essential element that may be toxic at higher concentrations, iron is found to be an abundant element in the studied stations with mean values of $22680 \pm 653 \mathrm{mg} \cdot \mathrm{kg}^{-1}$ with a $C I$ of 11.34 , confirming that iron is an element belongs to class 3. The sediment of station $1(21240 \pm 94.51$ $\left.\mathrm{mg} \cdot \mathrm{kg}^{-1}\right)$, and station $3\left(20220 \pm 193.13 \mathrm{mg} \cdot \mathrm{kg}^{-1}\right)$ belongs also to this class, while the recorded values at the sites 4 with $C I$ of $9.05\left(18100 \pm 246.5 \mathrm{mg} \cdot \mathrm{kg}^{-1}\right)$, and station 5 with $C I$ of $4.66\left(9320 \pm 541.27 \mathrm{mg} \cdot \mathrm{kg}^{-1}\right)$ belong to class 2 [ABRMC 1991]. Hence, their levels exceed the inferior limits in the major parts of the study zone, excepting the station 6 which doesn't exhibit iron pollution. Here, a decreasing concentration gradient of iron was remarkably seen from station 2 to station 6 (Figs. 2, 3). The relative important values of copper are recorded at the three stations: station named Sidi Salem (St1), having only depth of $10 \mathrm{~m}$, along with average concentration about of $81.9 \pm 8.17$ $\mathrm{mg} \cdot \mathrm{kg}^{-1}$ and $C I$ of 3.15 , Station of Wadi Seybouse (St2) presenting an average concentration of $86.32 \pm$ $7.6 \mathrm{mg} \cdot \mathrm{kg}^{-1}$ and $C I$ of 3.32 , and the last station is located in the harbour (St4), belonging to class 2 with the following average values of $104 \pm 10.15 \mathrm{mg} \cdot \mathrm{kg}^{-1}$ and CI of 4 [ABRMC 1991] (Figs. 2, 3). Furthermore, our findings showed a clear variability of lead $(\mathrm{Pb})$ level from one site to another, it varies from the maximum of $129.58 \pm 9.73 \mathrm{mg} \cdot \mathrm{kg}^{-1}$ and $C I$ of 5.89 in the harbour station (St4) belonged to class 2 , and the minimum of $21.53 \pm 3.08 \mathrm{mg} \cdot \mathrm{kg}^{-1}$ and $C I$ of 0.97 in AinAchir beach (St6). Also, we noticed that CI of 5.29 $\left(116.38 \pm 16.6 \mathrm{mg} \cdot \mathrm{kg}^{-1}\right)$ and $4.94(108.68 \pm 19.58$ $\mathrm{mg} \cdot \mathrm{kg}^{-1}$ ) recorded in station of Wadi Seybouse and the station of Sidi Salem are also part of class 2 [ABRMC 1991] (Figs. 2, 3). Regarding zinc concentration, the sediments of the whole study zone belong to class 1 , excepting station 3 that belongs to class 2 , and found as a non-negligible contamination site with $C I$ value of $3.34\left(293.92 \pm 9.91 \mathrm{mg} \cdot \mathrm{kg}^{-1}\right)$. The cadmium levels show that the sediment of the west coastal of Annaba Gulf belongs to class 1 with a maximum value of $C I$ about $2.5\left(1.503 \pm 0.186 \mathrm{mg} \cdot \mathrm{kg}^{-1}\right)$ at the harbour (St4). The relative results of nickel levels in the superficial sediments of the western region of Annaba Gulf showed variability in metal levels that do not explain metal pollution [ABRMC 1991], and hence maximum values of $67.95 \mathrm{mg} \cdot \mathrm{kg}^{-1}$ and $C I$ of 1.51 (St4) were noticed [ABRMC 1991] (Figs. 2, 3). The ANOVA test revealed a very highly significant spatial difference $(p \leq 0.001)$ for all the studied metals in superficial sediments. Consequently, the quantitative distribution of the metal levels in sediments of Annaba Gulf follows this order: $\mathrm{Fe}>\mathrm{Pb}>\mathrm{Cu}>\mathrm{Zn}>$ $\mathrm{Ni}>\mathrm{Cd}$.

The results of pollution load index $(P L I)(10 \mathrm{~m})$ and PLIs $(20 \mathrm{~m})$ of various elements are given in Figure 4. The range of $P L I$ s results were of 0.65 to 3.22 , and reaching the maximum value at the station 4 and the minimum one at the station 6 of $10 \mathrm{~m}$ of depth. The PLI of stations 1, 2, 3 and 4 (only for a depth of $10 \mathrm{~m}$ ) are up than 1 (Fig. 4). Thus, according to total levels of $P L I \mathrm{~s}$, the classification order of different stations in term of enrichment is as follows: St4 (Harbour $)>$ St 2 (Wadi Seybouse $)>$ St1 $($ Sidi Salem $)>$ St3 (Joinoville) $>$ St5 (Rizi Amor) $>$ St6 (Ain-Achir). The obtained results of ANOVA test has shown a very highly significant difference $(p \leq 0.001)$ between the sampling sites. The Figure 4 shows the variation of PLIs at different places.

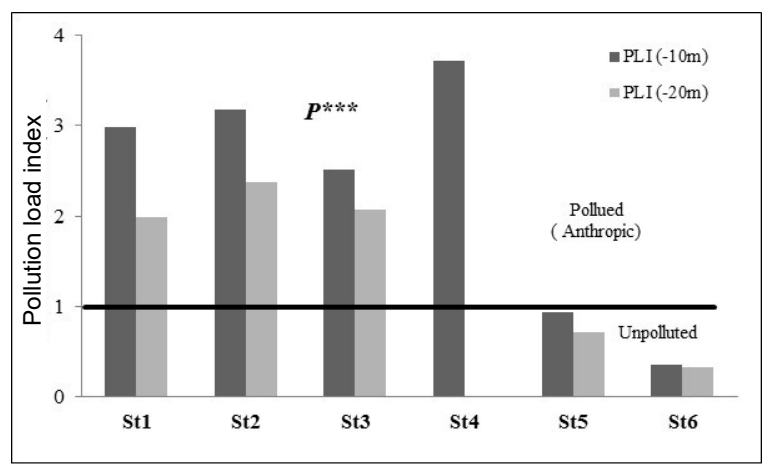

Fig. 4. Variations of the pollution load index (PLI) in the sediment samples collected from various stations; St1-St6 as in Fig. 2; source: own study

According to the French guidelines as well as a special view point, stations 1,2 and in particular station 4, a showing a marked polymetallic contamination by $\mathrm{Fe}$ and $\mathrm{Pb}$, in addition to a slight contamination by $\mathrm{Cd}$, making the sediment of these three stations a polluted zone of the highest importance on the Algerian coast. This is the most urbanized part of the bay, receiving the main exits of waste waters, whether 13 sewers discharging all forms of wastes (urban, industrials and pluvial). Thus, the network between the bay and Seybouse River surrounding by an important siege of industrial activity, containing various industries, and consequently the domestic and industrial wastes are discharged in the river. Nevertheless, the generalized contamination of sediments of Annaba Gulf confirms the existence of a pollution source. Indeed, the coastal waters receive indirectly by watershed of Seybouse River, containing the industrial wastes coming from steel alloy manufacture of El Hadjar (10 km South of Annaba Gulf known as the highest industrial pole and the most diversified industry in Africa [BELABED et al. 2017], as well as they are directly affected by port/export of iron-ore of Annaba. Hence, the highest levels of zinc, lead and copper are noticed in the harbour, explaining the involved effect of the port activities and the large number of emissaries of the domestic waste.

This could be due to the wide use of antifouling paint in hull boat coverings [AUGIER et al. 1992], and to road traffic emissions containing high levels of lead $(\mathrm{Pb})$, and hence the metal contamination can be whether through the direct atmospheric disposition or the indirect way following the washout of road dust 
Table 4. Concentration of heavy metals in the sediment of Annaba Gulf and other coastal ecosystems in the whole world

\begin{tabular}{|c|c|c|c|c|c|c|c|}
\hline \multirow{2}{*}{ Area } & $\mathrm{Zn}$ & $\mathrm{Cu}$ & $\mathrm{Pb}$ & \multirow{2}{*}{$\begin{array}{l}\mathrm{Fe} \\
\%\end{array}$} & $\mathrm{Cd}$ & $\mathrm{Ni}$ & \multirow{2}{*}{ References } \\
\hline & \multicolumn{3}{|c|}{$\mathrm{mg} \cdot \mathrm{kg}^{-1}$ dry weight } & & \multicolumn{2}{|c|}{$\mathrm{mg} \cdot \mathrm{kg}^{-1}$ dry weight } & \\
\hline West coast of Annaba Gulf & $2.72-293.92$ & $13.22-104$ & $21.5-108.68$ & $2.4-226.8$ & $0.001-1.5$ & $0.76-67.95$ & present study \\
\hline Average Continental Crust & 52 & 25 & 14.8 & - & 0.1 & - & WEDEPOHL 1995 \\
\hline Annaba Gulf(Algeria) & $190.2-301.1$ & $15.0-60.3$ & $10.04-186.1$ & $13.1-459.91$ & $0.9-2.62$ & $17.3-51.6$ & BELABED et al. 2013b \\
\hline Ghazaouet Gulf (Algeria) & 190.24 & 39.53 & 31.78 & 14.50 & 1.68 & - & $\begin{array}{l}\text { BENGUEDDA-RAHAL } \\
2012\end{array}$ \\
\hline Gabs Gulf (Tunisia) & $5.2-716.5$ & $0.59-5.8$ & $3.8-13.9$ & - & $0.11-950$ & - & EL ZRELLI et al. 2015 \\
\hline Atlantic Coast (Morocco) & 378.98 & 98 & 159.98 & 195.17 & $0.003-0.07$ & - & NADEM et al. 2015 \\
\hline $\begin{array}{l}\text { Aghien Coast (Ivore } \\
\text { coast) }\end{array}$ & $10.68-55.11$ & $59.98-243$ & $0.16-3.41$ & $0.002-0.133$ & 0.15 & - & TRAORE 2014 \\
\hline Gulf of Guinea & $2.6-82.2$ & $0.2-29.3$ & $21-22.2$ & - & $0.1-0.4$ & $1.4-66.75$ & MAHU et al. 2015 \\
\hline $\begin{array}{l}\text { Jezan Coast (Saudi Ara- } \\
\text { bia) }\end{array}$ & 24.74 & 16.39 & 3.86 & - & 0.48 & 14.32 & $\begin{array}{l}\text { GOLAM-MORTUZA et } \\
\text { al. } 2017\end{array}$ \\
\hline Toulon Harbour (France) & $15-1880$ & $5.8-1080$ & $14-710$ & - & $0.004-3.4$ & $8-66$ & TESSIER 2012 \\
\hline San Pietro Island (Italy) & $35-62$ & $8.05-22.34$ & $14.28-29.19$ & - & $0.2-1.7$ & $9-36.17$ & DI LEO et al. 2013 \\
\hline Andam Island & $10.4-27.27$ & $6.64-7.04$ & - & $0.508-3.93$ & $0.69-1.96$ & $2.16-2.88$ & NoBI et al. 2010 \\
\hline South-East coast of India & $39.73-72.68$ & $1.35-15.75$ & $11.85-23.05$ & $1.75-4.35$ & $0.59-6.41$ & $39.1-59.76$ & BARATH et al. 2017 \\
\hline Coastal Pakistan & $26.68-111.3$ & $0.14-77.41$ & $24.68-42.39$ & $0.96-1.02$ & $1.11-1.46$ & $43.03-51.31$ & $\begin{array}{l}\text { SAHER, SIDDIQUI } \\
2016\end{array}$ \\
\hline Bengal Bay (Bangladesh) & - & 6.1 & 1.42 & - & 0.79 & 7.25 & KHAN et al. 2017 \\
\hline Laizhou Bay (China) & $38.22-73.81$ & $7.57-21.29$ & $9.65-17.65$ & - & $0.11-0.28$ & $12.85-25.35$ & ZHANG, GAO 2015 \\
\hline Baixada Santista (Brazil) & $5.81-133.64$ & $0.70-30.73$ & $1.29-48.19$ & $1.53-43.79$ & - & $0.94-19.27$ & KIM et al. 2016 \\
\hline
\end{tabular}

Source: own elaboration.

by rainwater [CONOR 1980]. The regulatory presence of nickel and cadmium could be related to domestic waste effluents and urban sewers (fuels, batteries and other electrical apparatus, as well as the mud bottom of harbour is considered to be as a carrier substrate on which nickel can be highly absorbed [GUILLON-COTTARD 1997]. The significant concentration with metal detected at a depth of $10 \mathrm{~m}$. Indeed, the collected sediments from the coastal region are very close to waste zones, exhibiting that all elements present at concentrations slightly very higher from the coast to the depth. This result is in line with those obtained by [CHRISTOPHORIDIS et al. 2009] in the Gulf of Thermai (Greece), and by [MC ALISTER et al. 2005]. These authors have found that metals entering into waters and sediments are transported and enter the geochemical cycle and are slightly retained at the coastal edges.

The pollution load index ( $P L I)$ of the west coastal sediments of Annaba Gulf was calculated in order to understand the changes in the contamination levels of sediments in various stations. Very low values of $P L I$ $(<1)$ do not involve appreciable anthropic effects [TOMLINSON et al. 1980]. Also, the calculated values of PLI showed that the studied sediments, excepting those of stations St5 and St6 were up than 1. This enrichment indicated that these sediments were polluted by heavy metals resulting from the common or different original source $(P L I>1)$, dumping urban and industrial waste effluents in these stations. Additionally, the selected metals in this study are considered as an original crust of stations 5 and 6, where $P L I$ becomes inferior than $1(P L I<1)$.

The comparison of trace element levels with those reported for another coastal region in the average continental crust [WEDEPOHL 1995] are given in
Table 3 . In the study zone, the average concentrations of $\mathrm{Pb}, \mathrm{Cd}, \mathrm{Zn}$ and $\mathrm{Cu}$ have showed higher values than those found in the average continental crust [WEDEPOHL 1995] (Tab. 4). The current values of iron are higher than those of the other coastal regions, whilst the reported levels for the Annaba Gulf [BELABED et al. 2013] were of the same order of magnitude than those of the present study. Moreover, the obtained results of nickel are comparable to different reports for other coastal regions, since the concentration of zinc is comparable or superior to those of other regions of Tunisia and France. In addition, the higher concentrations of $\mathrm{Zn}, \mathrm{Cu}$ and $\mathrm{Pb}$ were found as 15$1880 \mathrm{mg} \cdot \mathrm{kg}^{-1}$, and $14-710 \mathrm{mg} \cdot \mathrm{kg}^{-1}$ respectively, in the Toulon Harbour of France [TESSIER 2012] (Tab. 4).

\section{METALLIC LEVELS IN FISH TISSUES}

Figure 5 shows a strong variability between the sampling stations, indicating that the higher levels are those of iron in all harvests, with a maximal value of $199.67 \pm 17.5 \mathrm{mg} \cdot \mathrm{kg}^{-1}$ recorded in the harvested individuals at the station of Wadi Seybouse, and a minimal value of $95.87 \pm 11.5 \mathrm{mg} \cdot \mathrm{kg}^{-1}$ recorded in the harvested individuals at the station of Ain-Achir. Unlike to zinc concentration in stations 5 and 6 , zinc exhibits higher values than those of the recommended nutritional guidelines given by WHO/USEPA, with a maximum value of $161 \pm 1.82 \mathrm{mg} \cdot \mathrm{kg}^{-1}$ recorded in the harvested fishes in station 4 (Fig. 5). Moreover, the results of fishes caught from the studied stations, excepting those of station 6 , have shown high values of lead, exceeding the guideline values [EC 2006], and subsequent they reach the maximal value for the individual lots of station $4\left(2.39 \pm 0.092 \mathrm{mg} \cdot \mathrm{kg}^{-1}\right)$. On the other hand, the concentration of the remaining 

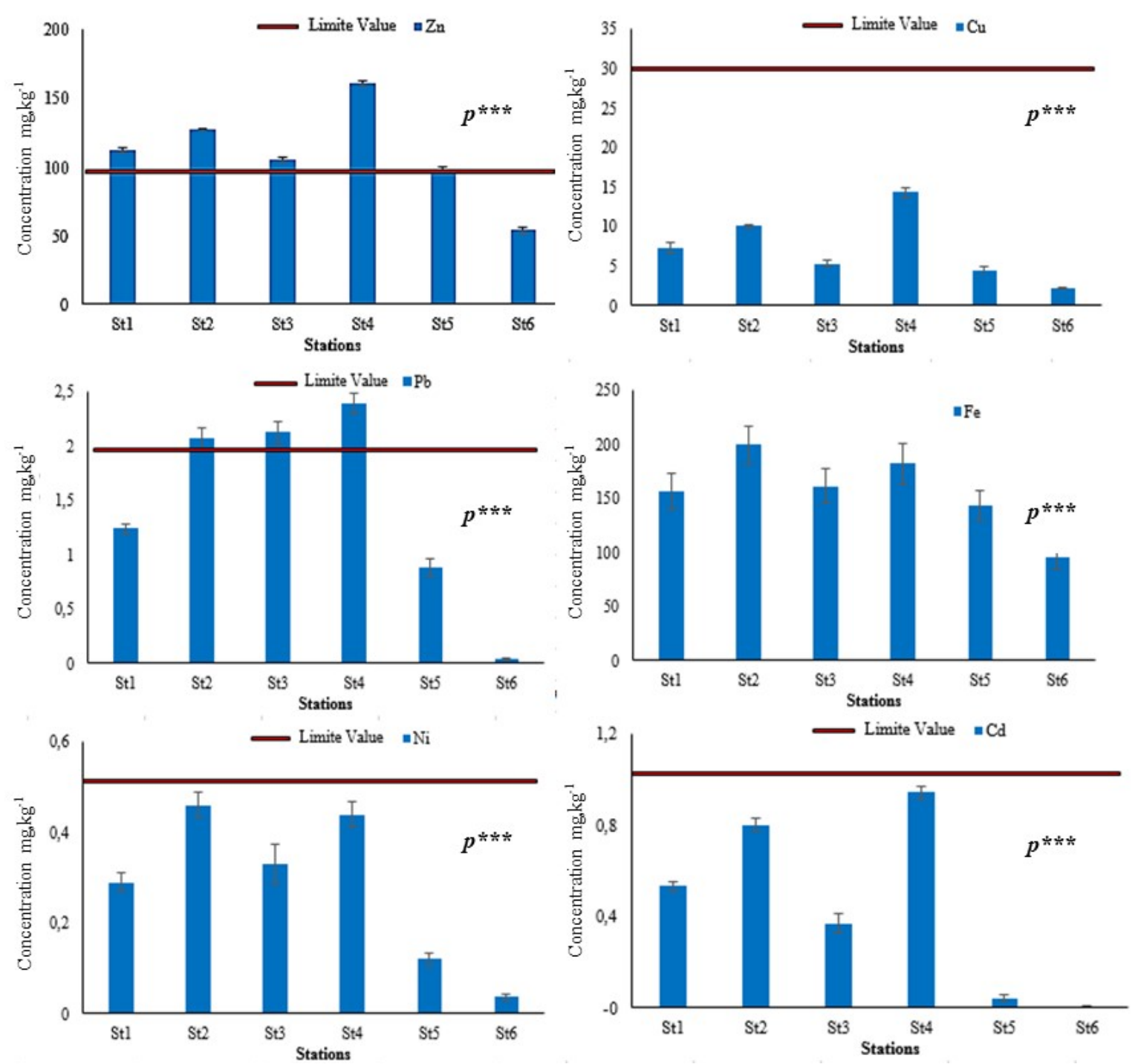

Fig. 5. Mean concentrations of metals in fish tissues ( $\mathrm{mg} \cdot \mathrm{kg}^{-1}$ dry weight) of the six selected stations; $p \leq 0.001$; source: own study

metals $(\mathrm{Cu}, \mathrm{Ni}$ and $\mathrm{Cd})$ in fish muscles of all harvest are lower than the maximal value limits given by WHO/USEPA, and therefore the maximum values were found to be as $14.35 \pm 0.61 \mathrm{mg} \cdot \mathrm{kg}^{-1}, 0.46$ $\pm 0.027 \mathrm{mg} \cdot \mathrm{kg}^{-1}$ and $0.8 \pm 0.042 \mathrm{mg} \cdot \mathrm{kg}^{-1}$ for copper, nickel and cadmium, respectively (Fig. 5). In contrast, the cadmium level is $0.05 \mathrm{mg} \cdot \mathrm{kg}^{-1}$, as given by the regulations of European Community [EC 2006], and therefore the caught fishes in stations 1, 2, 3 and 4 are contaminated by metals (Tab. 3 ). The data analyses showed the following bioaccumulate order of heavy metals in $M$. cephalus issue: $\mathrm{Fe}>\mathrm{Zn}>\mathrm{Pb}>\mathrm{Cu}>\mathrm{Ni}$ $>\mathrm{Cd}$. Similarly of the sediment, the ANOVA test revealed a very highly significant spatial difference $(p \leq 0.001)$ for all the studied metals in muscle of fish.

The enrichment order of the individuals in stations for the metallic elements obeys to their concentration order in sediments. Noteworthy, the higher levels of metals were recorded in fish samples collected from the proximity of human activities, such as beaches of harbor, Sidi Salem, Joinoville, and station of Wadi Seybouse. This metal enrichment is strongly related to the industrial wastes of steel complex conveyed by Seybouse River to Gulf, and to the road axis, as well as harbour activity leading to metal contaminations, including lead, copper, zinc, and in particular iron. The lead is used as an anti-detonator in gasoline, since the contamination by this element is related to anthropic activities [LI et al. 2003]. The agriculture activity could also promote the increase of copper, zinc and cadmium concentrations. As far as known, $M$. cephalus is a pelagic, omnivorous species, and narrowly related to the sediments, and also it's characterized by weak mobility and food rich by algae, polychaetes, crustaceans, gastropods and fishes [STANCHEVA et al. 2013]. The sediment forms a reservoir of metals and the other aquatic environmental pollutants. In relation to their mobility and food preferences [FOWLER 1986], the fishes survive close to the sea bottom, and thus reflect the concentrations of the environmental metallic elements [ENNOURI et al. 2013]. Importantly, the bioaccumulation is also related with feeding, swimming and the metabolic activity of the individual and species, and may depend on size, 
Table 5. Comparison of metal concentrations in muscle of flathead grey mullet (Mugil cephalus) of coastal region of Annaba with those found in others in the world $\left(\mathrm{mg} \cdot \mathrm{kg}^{-1}\right.$ dry wt)

\begin{tabular}{|l|c|c|c|c|c|c|l|}
\hline \multicolumn{1}{|c|}{ Area } & $\mathrm{Zn}$ & $\mathrm{Cu}$ & $\mathrm{Pb}$ & $\mathrm{Fe}$ & $\mathrm{Cd}$ & $\mathrm{Ni}$ & Reference \\
\hline West coast of Annaba Gulf $^{\prime}$ & 107.98 & 8.10 & 1.21 & 147.73 & 0.475 & 0.248 & present study \\
\hline FAO/WHO a) & 100 & 30 & 2 & - & 2 & 1 & 1984 \\
$\mathrm{SEPA}^{\text {b) }}$ & 100 & 20 & 9 & - & 10 & 0.2 & 2005 \\
$\mathrm{CE}$ & - & - & 0.30 & - & 0.050 & - & 2006 \\
\hline Middle East coast (Tunisia) & 180 & 19.12 & - & - & 0.28 & - & HAMZA-CHAFFAI et al. [1996] \\
\hline North-East Mediterranean (Turkey) & 37.39 & 4.41 & 5.32 & - & 0.66 & - & CANLI and ATLI [2003] \\
\hline Black Sea (Turkey) & 86.2 & 2.14 & 0.68 & - & 0.35 & - & \multirow{2}{*}{ YILMAZ [2009] } \\
Lake Köyceğiz - Mugla (Turkey) & 394.4 & 25.4 & 1.72 & - & 0.48 & - & \\
\hline Coast of Rio de Janeiro (Brazil) & 0.02 & 0.005 & 0.0008 & - & 0.0001 & - & MEDEIROS et al. [2012] \\
\hline Lake Bafa; Eastern Aegean (Greece) & 14.9 & 1.25 & 0.91 & - & 0.0235 & - & AYDIN-ONEN et al. [2015] \\
\hline Coast of Dakar (Senegal) & 160 & 373 & 0.39 & - & 1.79 & - & \multirow{2}{*}{ DiOP et al. [2016b] } \\
\hline Estuary of Saint Louis (Senegal) & 98 & 180 & 0.08 & - & 2.31 & - & \\
\hline
\end{tabular}

a) Codex Alimentarius Commission 1984. ${ }^{\text {b) }}$ SEPA China 2005.

Source: own study and own elaboration acc. to literature.

Table 6. Pearson correlation coefficient analysis of trace metals in fish and the coastal sediment of Annaba

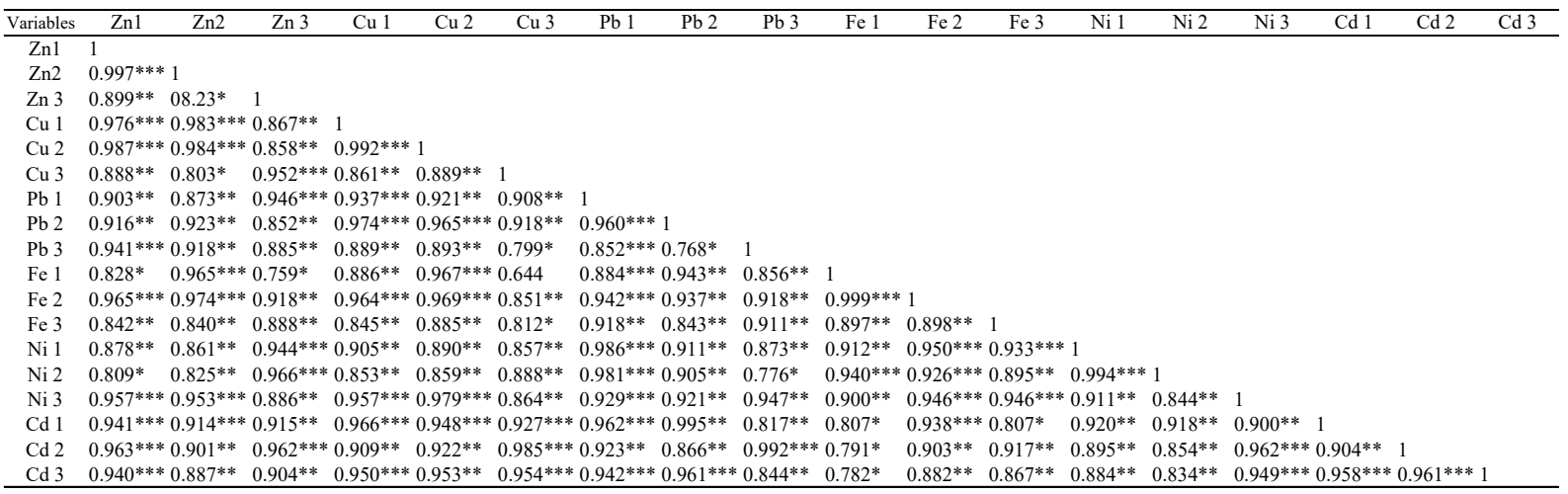

Explanations: $1=10 \mathrm{~m}$ of depth, $2=20 \mathrm{~m}$ of depth, $3=$ in fish muscle, ${ }^{*}=p \leq 0.05, * *=p \leq 0.01, * * *=p \leq 0.001$.

Source: own study.

feeding habits, ability of biological concentration of every species [KWOK et al. 2014]. This study, therefore presents new information about the distribution of metals in fishes along of Annaba Gulf.

It's interesting to compare the concentrations found in muscles of Mugil cephalus collected from Annaba Gulf with those obtained in other regions in the world subjected also to anthropic pressure (Tab. 5).

Among all the metal elements of the studied zone, only zinc concentrations do not conform with the dietary guidelines, and thus pose a human health risk according to FAO/WHO (Tab. 5). Regarding zinc and copper concentrations, the most studies on various regions of the world revealed consistent concentrations with dietary guidelines, reaching a high concentration of $394.4 \mathrm{mg} \cdot \mathrm{kg}^{-1}$ for zinc, and $180 \mathrm{mg} \cdot \mathrm{kg}^{-1}$ for copper [DIOP et al. 2016]. Overall, the mullet collected from Senegal was found to have higher muscular concentrations for copper, cadmium and zinc compared to dietary guidelines.

The Pearson correlation coefficient analysis and the significance levels of the obtained results are given in Table 6 , indicating that all coefficients are strongly correlated ( $p \leq 0.5,0.01,0.001)$, and consequently these heavy metals are likely resulted from the common source: natural or anthropic. Besides, a weak correlation (0.644) was found between copper and iron (Tab. 6). The significant positive correlation calculated using Pearson correlation coefficient test analysis confirms the existence of homogeneity between the presence of metals in sediments and fish.

\section{CONCLUSIONS}

The results showed that the sediments of Annaba Gulf contain some of the studied metals. The determination of $C I$ and $P L I$ revealed an important polymetallic contamination by iron, lead and copper in stations 1, 2, 3 and 4, and however, slightly important for cadmium where the most metal concentrations become slightly inferior at the depth $(20 \mathrm{~m})$. Addionally, the concentrations of heavy metals in muscles of mullet (M. cephalus) were also lower than those of the current world guidelines (WHO/USEPA, EC), except zinc, cadmium and lead concentrations in stations 1, 2, 3 and 4. On the other part, the positive correlation was observed between the metal concentrations in sediments and tissues of $M$. cephalus, indicating that these elements are released from common origin of the anthropic activity. These metallic element enrichments are somehow related to domestic and industrial wastewater inputs of the town that flow in these stations, without pretreatment process. Indeed, zinc, copper and lead are considered as metallic 
elements, characterizing the urban pollution and hence the continued monitoring would be mainly carried out in the polluted zones, in particular, the port station in which important metallic waste discharges, including the studied metals were remarkably noticed. Moreover, the high levels and hazardous of zinc and lead bioaccumulations in M. cephalus fish of Annaba Gulf are of concerns for the authorities, due to the tendency of these metals in causing serious body diseases. A regular monitoring program for heavy metals is recommended in order to protect these compartments and to reduce the environmental risks. The most protected places are beach of Rizi Amor, and especially station of Ain-Achir. The later does not receive any waste discharges, and thereby it benefits a continuing renewal of waters following the current regimen of the bay (high currentology).

\section{Acknowledgements}

The authors warmly thank Doctor Yahiaoui Idris, for the valuable scientific and moral support throughout the present research study.

\section{REFERENCES}

Abdennour C., Smith B.D., Boulakoud M.S., Samraoui B., RaInBOW P.S. 2000. Trace metals in shrimps and sediments from Algerian water. Journal of Materials and Environmental Science. Vol. 3 p. 9-12.

ABHA 1999. Report $N^{\circ} 1$. L'Agence du Bassin Hydrographique d'Annaba, Le Bassin de la Seybouse pp. 35.

ABRMC 1991. Pollution du Rhône [Pollution of the Rhône]. Synthèse des connaissances ministère de l'environnement français. Vol. 7. No. 71470 pp. 26.

Aminot A., Chausseried M. 1983. Manual of chemical analyses in the marine environment. Paris. National Center for the Exploitation of the Oceans. ISBN 2902721-10-2 pp. 396.

Augier H., PARK W.K., RAMONDA G. 1992. Study of geographical and seasonal metal content variations in different parts of edible sea urchins Paracentrotus lividus Lamarck from three Provençal test areas. Revue internationale d'océanographie médicale. No. 107-108 p. 75-89.

Barath Kumar S., Padhi R.K., Mohanty A.K. SatPathy K.K. 2017. Elemental distribution and trace metal contamination in the surface sediment of south east coast of India. Marine Pollution Bulletin. Vol. 114. Iss. 2 p. 1164-1170.

Belabed B.E., Affray X., DhiB A., Fertouna-Belakhal M., Turki S., Aleya L. 2013. Factors contributing to heavy metal accumulation in sediments and in the intertidal mussel Perna perna in the Gulf of Annaba (Algeria). Marine Pollution Bulletin. Vol. 74. Iss. 1 p. $477-$ 489.

Belabed B.E., Meddour A.N., SAmraoui B. ChenchounI H. 2017. Modeling seasonal and spatial contamination of surface waters and upper sediments with trace metal elements across industrialized urban areas of the Seybouse watershed in North Africa. Environmental Monitoring and Assessment. Vol. 189 p. 1-19.

BenguedDA-RAHAL W. 2012. Contribution à l'étude de la bioaccumulation métallique dans les sédiments et différents maillons de la chaine trophique du littoral Extrême Ouest Algérien [Contribution to the study of metallic bioaccumulation in sediments and different links in the tropic chain of the extreme west coast of Algeria]. PhD Thesis. Tlemcen. University of Tlemcen pp. 117.

Bryan G.W. 1984. Pollution due to heavy metals and their compounds. In: Marine ecology. Ed. O. Kinne. 5. Ocean management: 3. Pollution and protection of the seas, radioactive materials, heavy metals and oil p. 1289-1431.

BugGy C.J., ToBIN J.M. 2008. Seasonal and spatial distribution of metals in surface sediment of an urban estuary. Environnemental Pollution. Vol. 155. Iss. 2 p. 308 319.

Canli M., AtLi G. 2003. The relationships between heavy metal $(\mathrm{Cd}, \mathrm{Cr}, \mathrm{Cu}, \mathrm{Fe}, \mathrm{Pb}, \mathrm{Zn})$ levels and the size of six Mediterranean fish species. Environmental Pollution. Vol. 121. Iss. 1 p. 129-136.

Chen H., Chen R., Teng Y., Wu J. 2016. Contamination characteristics, ecological risk and source identification of trace metals in sediments of the Lean River (China). Ecotoxicology and Environmental Safety. Vol. 125 p. 85-92.

Christophoridis C., Dedepsidis D., Fytianos K. 2009. Occurrence and distribution of selected heavy metals in the surface sediments of the Thermaikos Gulf, N. Greece. Assessment using pollution indicators. Journal of Hazardous Materials. Vol. 168 p. 1082-1091.

Codex Alimentarius Commission: 2001. Lead: maximum levels. Vol. 1. Codex Stan 230.

CONOR R. 1980. Metal contamination of food. London. Applied Science Publish. Ltd. ISBN 0853349053 pp. 235.

DeBIEChe T.H. 2002. Evolution de la qualité des eaux (salinité, azote et métaux lourds) sous l'effet de la pollution saline, agricole et industrielle: Application à la basse plaine de la Seybouse (N.E algérien) [Evolution of water quality (salinity, nitrogen and heavy metals) under the effect of saline, agricultural and industrial pollution: Application to the low plain of Seybouse (Algerian N.E)]. PhD Thesis. Besançon. University of Franche-Comté pp. 199.

Di Leo A., AnNicchiarico C., Cardellicchio N., Spada L., Giandomenico S. 2013. Trace metal distributions in Posidonia oceanica and sediments from Taranto Gulf (Ionian Sea, Southern Italy). Mediterranean Marine Science. Vol. 14. Iss. 1 p. 204-213.

Diop M., Howsam M., Diop C., Goossens J.F., Diouf A., AMARA R. 2016. Assessment of trace element contamination and bioaccumulation in algae (Ulva lactuca), mussels (Perna perna), shrimp (Penaeus kerathurus), and fish (Mugil cephalus, Saratherondon melanotheron) along the Senegalese coast. Marine Pollution Bulletin. Vol. 103. Iss. 1 p. 339-343.

EC 2006. Commission regulation (EC) No 1881/2006 of 19 December 2006 setting maximum levels for certain contaminants in foodstuffs. OJ EU L 364.

El Zrelli R., Courjault-Rade P., Rabaoui L., Cstet S., Michel S., Bejaoui N. 2015. Heavy metal contamination and ecological risk assessment in the surface sediments of the coastal area surrounding the industrial complex of Gabes city, Gulf of Gabes, SE Tunisia. Marine Pollution Bulletin. Vol. 101. Iss. 2 p. 922-929.

EnNouri R., Mili S., Chouba L. 2013. La contamination metallique du rouget de vase (Mullus barbatus) et de la sardinelle (Sardinella aurita) du golfe de Tunis [Metallic contamination of red mullet (Mullus barbatus) and round sardinella (Sardinella aurita) from the Gulf of Tunis Cybium]. International Journal of Ichthyology. Vol. 37. Iss. 1-2 p. 49-59. 
FOWLER S.W. 1986. Trace metal monitoring of pelagic organisms from the open Mediterranean Sea. Environmental Monitoring and Assessment. Vol. 7. Iss. 1 p. 59-78.

Golam-MortuZa M., AL-Misned F.A. 2017. Environmental contamination and assessment of heavy metals in water, sediments, and shrimp of Red Sea coast of Jizan, Saudi Arabia. Journal of Aquatic Pollution and Toxicology. 1:1.

GUILLON-COTTARD I. 1997. Les ports de plaisance et leur impact sur l'environnement maritime et terrestre : étude de cas (Provence, Méditerranée, France) [Harbours and its impact on the maritime and terrestrial environment: case study (Provence, Mediterranean, France)]. PhD Thesis. Marseille. Paul Cézanne University AixMarseille III pp. 486.

Hamza-Chaffai A., Romeo M., Abed A.E. 1996. Heavy metals in different fishes from the middle eastern coast of Tunisia. Bulletin of Environmental Contamination and Toxicology. Vol. 56 p. 766-773.

JoAnNy M., Chaussepied M., Corre F. 1983. Presentation of oceans results. Oceanological Center of Brittany (CNEXO/COB). pp. 49.

Khan M.Z.H., Hasan M.R., Khan M., AKTaR S., Fatema K. 2017. Distribution of heavy metals in surface sediments of the Bay of Bengal Coast. Journal of Toxicology. Vol. 2017 p. 7. DOI 10.1155/2017/ 9235764.

Khelifi-Touhami M., OUnissi M., SAKer I., Haridi A., DJorfi S., ABdenNour C. 2006. The hydrology of the Mafrag estuary (Algeria): Transport of inorganic nitrogen and phosphorus to the adjacent coast. Journal of Food Agriculture and Environment. Vol. 4 p. 340-346.

Kim B.S.M., Salaroli A.B., De Lima Ferreira P.A., SARtoretto J.R., De MahiQues M.M., Figueira R.C.L. 2016. Spatial distribution and enrichment assessment of heavy metals in surface sediments from Baixada Santista, Southeastern Brazil. Marine Pollution Bulletin. Vol. 103. Iss. 1-2 p. 333-338.

Kucuksezgin F., Kontas A., Altay O., Uluturhan E., DARILMAZ E. 2006. Assessment of marine pollution in Izmir Bay: Nutrient, heavy metal and total hydrocarbon concentrations. International Environment. Vol. 32 p. 41-51.

Kwok C., Liang Y., WANG H., Dong Y., Leung S., WANG M.H. 2014. Bioaccumulation of heavy metals in fish and ardeid at Pearl River Estuary, China. Ecotoxicology and Environmental Safety. Vol. 106 p. 62-67.

Lafabrie C., Pergent G., Kantin R., Pergent-Martini C., Gonzalez J.L. 2007. Trace metals assessment in water, sediment, mussel and seagrass species - Validation of the use of Posidonia Oceanica as a metal biomonitor. Chemosphere. Vol. 68. Iss. 11 p. $2033-$ 2039.

Lenoble V., Omanovic D., Garnier C., Mounier S., Đonlagic N., Le Poupon C., Pizeta I. 2013. Distribution and chemical speciation of arsenic and heavy metals in highly contaminated waters used for health care purposes (Srebrenica, Bosnia, and Herzegovina). Science of the Total Environment. Vol. 443 p. 420-428.

Li X.D., Wang D.C., Wai O.M.Ho, Li Y.S., LiU W.X., SHEN Z.G. 2003. Multivariate statistical study of heavy metal enrichment in sediments of the early river estuary. Environmental Pollution. Vol. 121 p. 377-388.

Mahu E., Nyarko E., Hulme S., Coale K.H. 2015. Distribution and enrichment of trace metals in marine sediments from the Eastern equatorial Atlantic, off the coast of Ghana in the Gulf of Guinea. Marine Pollution Bulletin. Vol. 98 p. 301-307.

Mc Alister J.J., Smith B.J., Neto J.B., Simpson J.K. 2005. Geochemical distribution and bioavailability of heavy metals and oxalate in street sediments from Rio de Janeiro, Brazil: A preliminary investigation. Environmental Geochemistry and Health. Vol. 27 p. 429 441.

Medeiros R.J., Dos Santos L.M.G., Freire A.S., SAntelLI R.E., Braga A.M.C.B., Krauss T.M., Jacob S.C. 2012. Determination of inorganic trace elements in edible marine fish from Rio de Janeiro State, Brazil. Food Control. Vol. 23. Iss. 2 p. 535-541.

NADEM S., El-Baghdadi M., Rais J., BaraKat A. 2015. Evaluation of heavy metal contamination of sediments of the estuary of the Bouregreg (Atlantic Coast, Morocco). Journal of Materials and Environmental Science. Vol. 6. Iss. 11 p. 3338-3345.

Nobi E.P., Dilipan E., Thangaradjou T., Sivakumar K., KANNAN L. 2010. Geochemical and geostatistical assessment of heavy metal in the sediments of different coastal ecosystems of Andaman Islands, India. Estuarine, Coastal and Shelf Science. Vol. 87 p. 253-264.

PeKEY H. 2006. The distribution and sources of heavy metals in Izmir Bay surface sediments affected by a polluted stream. Marine Pollution Bulletin. Vol. 52 p. $1197-1208$.

PNUE 1985. Rapport de la Quatrième réunion ordinaire des Parties contractantes à la convention pour la protection de la mer Méditerranée contre la pollution et aux protocoles y relatifs [Report of the Fourth Ordinary Meeting of the Contracting Parties to the Convention for the Protection of the Mediterranean Sea against Pollution and Related Protocols]. 9-13.09.1985 Gênes. Document UNEP/IG.56/5. Programme des Nations Unies pour l'environnement. Athènes p. 689-718.

Rahman M.S., Molla A.H., SaHa N., Rahman A. 2012. Study on heavy metals levels and its risk assessment in some edible fishes from Bangshi River, Savar, Dhaka, Bangladesh. Food Chemistry. Vol. 134 p. 1847-1854.

RuQia N., Muslim M., Muhammad M., Hameed U.R., NAVEED U.R. 2015. Accumulation of heavy metals (Ni, $\mathrm{Cu}, \mathrm{Cd}, \mathrm{Cr}, \mathrm{Pb}, \mathrm{Zn}, \mathrm{Fe}$ ) in the soil, water and plants and analysis of physicochemical parameters of soil and water collected from Tanda Dam Kohat. Journal of Pharmaceutical Sciences and Research. Vol. 7 p. 89-97.

SAHER N.U., SidDiQui A.S. 2016. Comparison of heavy metal contamination during the last decade along the coastal sediment of Pakistan: multiple pollution indices approach. Marine Pollution Bulletin. Vol. 105. Iss. 1 p. $403-410$.

SAlOMONS W., FörSTNER U. 1984. Sediments and the transport of metals. In: Metals in the hydrocycle. Springer p. 63-98.

SEPA 2005. The limit of pollutant in food. State Environmental Protection Administration. China. GB 2762. Vol. 49. Iss. 1 p. 174-196.

Stancheva M., Makedonski L., Petrova E. 2013. Determination of heavy metals $(\mathrm{Pb}, \mathrm{Cd}, \mathrm{As}$ and $\mathrm{Hg})$ in black sea gray mullet (Mugil cephalus). Bulgarian Journal of Agricultural Science. Vol. 19. Iss. 1 p. 30-34.

TESSIER E. 2012. Diagnosis of sediment contamination by metals in the Toulon harbour and mechanisms controlling their mobility. PhD Thesis. Toulon. Toulon University pp. 292.

TOMLINSON D.C., WiLSON J.G., HARRIS C.R., JeFFrEY D.W. 1980. Problems in the assessment of heavy metals in es- 
tuaries and the formation pollution index. Helgoländer Meeresuntersuchungen. Vol. 33 p. 566-575.

Traore A., Soro G., Ernest Ahoussi K., Siaka B., Soro N., BIEMI J. 2014. Niveau de contamination en métaux lourds des sédiments d'une lagune tropicale : la lagune Aghien (Sud-Est de la Côte d'Ivoire) [Level of heavy metals contamination of tropical lagoon sediments: Aghien Lagoon (South-East of Côte d'Ivoire)]. Afrique Science. Vol. 10. Iss. 3 p. 73-88.

UNEP 1982. Determination of total $\mathrm{Cd}, \mathrm{Zn}, \mathrm{Pb}$ and $\mathrm{Cu}$ in selected marine organism by atomic absorption spectrophotometry. Reference Methods for Marine Pollution Studies. No. 16 pp. 111.

UNEP 1984. Determination of total cadmium, zinc, lead and copper in selected marine organisms by flameless atomic absorption spectrophotometry. Reference Methods for Marine Pollution Studies. United Nations Environment Programme. No. 44. Rev. 1 p. 7-34.

USEPA 2002. Supplemental guidance for developing soil screening levels for superfund sites. Washington DC, USA. Environmental Protection Agency. Office of Solid Waste and Emergency Response OSWER 9355. 4-24 pp. 187.
WeDEPOHL K.H. 1995. The composition of the continental crust. Geochimica et Cosmochimica Acta. Vol. 59 p. 1217-1232.

WHO 2004. Guidelines for drinking-water quality. $3^{\text {rd }}$ ed. Geneva. World Health Organization.Vol. 1 pp. 515.

YAKINOV M.M., Tummis K.N., Golyshin P.N. 2007. Obligate oil-degrading marine bacteria. Current Opinion Biotechnology. Vol. 18. Iss. 3 p. 257-266.

YILMAZ F. 2009. The comparison of heavy metal concentrations $(\mathrm{Cd}, \mathrm{Cu}, \mathrm{Mn}, \mathrm{Pb}$, and $\mathrm{Zn})$ in tissues of three economically important fish (Anguilla anguilla, Mugil cephalus and Oreochromisni loticus) inhabiting Köcegiz Lake-Mugla (Turkey). Turkish Journal of Science Technology. Vol. 4 p. 7-15.

YuJun Y., Zhifeng Y., Shanghong Z. 2011. Ecological risk assessment of heavy metals in sediment and human health risk assessment of heavy metals in fishes in the middle and lower reaches of the Yangtze River basin. Environmental Pollution. Vol. 159 p. 2575-2585.

ZHANG J., GAO X. 2015. Heavy metals in surface sediments of the intertidal Laizhou Bay, Bohai Sea, China: Distributions, sources and contamination assessment. Marine Pollution Bulletin. Vol. 98. Iss. 1-2 p. 320-327.

\section{Naouel OUALI, Bourhane E. BELABED, Fadila ZEGHDOUDI, Mounira RACHEDI}

\section{Ocena zanieczyszczenia metalami osadów i tkanek cefala pospolitego (Mugil cephalus Linnaeus, 1758) ze wschodniego wybrzeża Algierii}

\section{STRESZCZENIE}

W pracy oceniono poziom zanieczyszczenia strefy przybrzeżnej w okolicach Annaby na podstawie spektrofotometrycznych analiz metali $(\mathrm{Fe}, \mathrm{Cu}, \mathrm{Pb}, \mathrm{Zn}, \mathrm{Ni}$ and $\mathrm{Cd}) \mathrm{w}$ osadach na różnej głębokości $(10$ i $20 \mathrm{~m})$ i w mięśniach cefala pospolitego (Mugil cephalus) jako organizmu wskaźnikowego. W okresie zimowym (2014 r.) zebrano 12 próbek osadów powierzchniowych i łącznie 24 ryby. Po wysuszeniu, pokruszeniu i przesianiu próbek do stężonych kwasów dodano $0,5 \mathrm{~g}$ suchej masy każdej próbki. Wyniki dowodzą, że stężenie niektórych metali przekracza dopuszczalne normy, a osady w zatoce są zanieczyszczone żelazem, ołowiem i miedzią. Wskaźnik zanieczyszczenia $(C I)$ kształtował się następująco: $\mathrm{Fe}>\mathrm{Pb}>\mathrm{Cu}>\mathrm{Zn}>\mathrm{Ni}>\mathrm{Cd}$, przy czym większe stężenie większości metali notowano na głębokości $20 \mathrm{~m}$.

Średnie stężenie metali w mięśniach ryb układało się natomiast w porządku: $\mathrm{Fe}>\mathrm{Zn}>\mathrm{Pb}>\mathrm{Cu}>\mathrm{Ni}>\mathrm{Cd}$. Konsumpcja ryb z niektórych skażonych stanowisk może być niebezpieczna, ponieważ stężenie ołowiu, kadmu i cynku przekracza międzynarodowe standardy. Ponadto, silna dodatnia korelacja między stężeniem metali w osadach i w rybach dowodzi, że metale te pochodzą z tych samych antropogenicznych źródeł takich jak zrzuty ścieków bytowych, portowych, przemysłowych i rolniczych. Potwierdza to oznaczony wskaźnik ładunku zanieczyszczeń $(P L I)$. W podsumowaniu zaleca się wdrożenie regularnego programu monitoringu w celu ochrony organizmów wodnych i ograniczenia ryzyka środowiskowego.

Słowa kluczowe: glębokość wody, metale ciężkie, osad, ryby, toksyczność 